\title{
L Uusuersily
}

\section{Computer-enhanced grammar teaching}

Barr, D. (2008). Computer-enhanced grammar teaching. In F. Zhang, \& B. Barber (Eds.), Handbook of Research on computer-enhanced language acquisition and learning (pp. 101-114). IGI Global.

Link to publication record in Ulster University Research Portal

\section{Published in:}

Handbook of Research on computer-enhanced language acquisition and learning

Publication Status:

Published (in print/issue): 01/01/2008

\section{Document Version}

Publisher's PDF, also known as Version of record

\section{General rights}

Copyright for the publications made accessible via Ulster University's Research Portal is retained by the author(s) and / or other copyright owners and it is a condition of accessing these publications that users recognise and abide by the legal requirements associated with these rights.

\section{Take down policy}

The Research Portal is Ulster University's institutional repository that provides access to Ulster's research outputs. Every effort has been made to ensure that content in the Research Portal does not infringe any person's rights, or applicable UK laws. If you discover content in the Research Portal that you believe breaches copyright or violates any law, please contact pure-support@ulster.ac.uk. 


\section{Handbook of Research on Computer-Enhanced Language Acquisition and Learning}

Felicia Zhang

University of Canberra, Australia

Beth Barber

University of Canberra, Australia

Information Science INFORMATION SCIENCE REFERENCE REFERENCE 


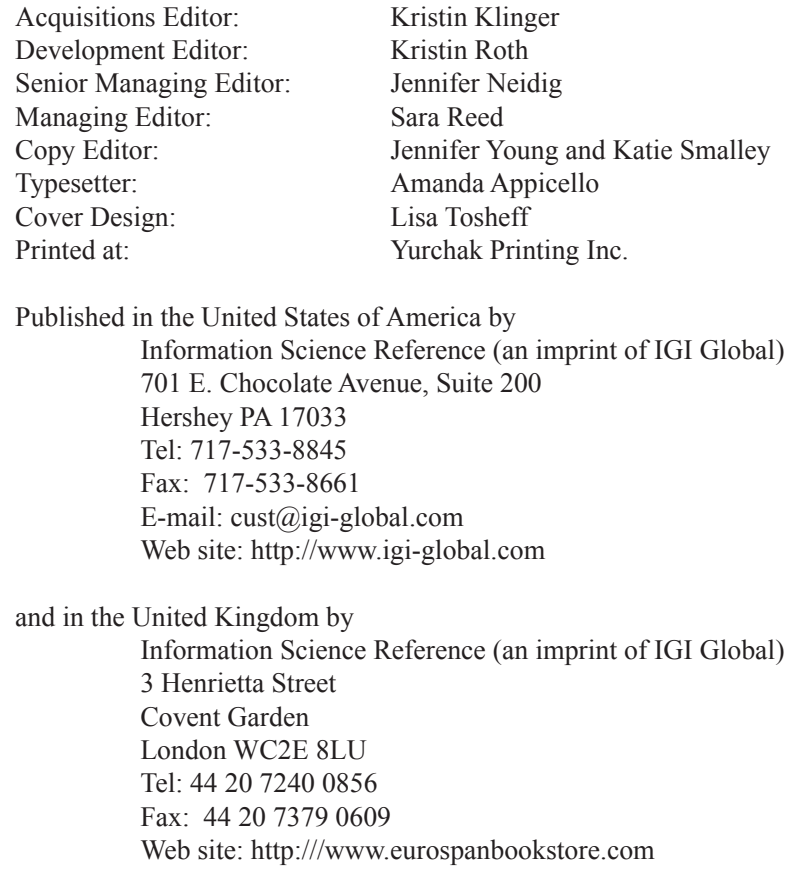

Copyright (C) 2008 by IGI Global. All rights reserved. No part of this publication may be reproduced, stored or distributed in any form or by any means, electronic or mechanical, including photocopying, without written permission from the publisher.

Product or company names used in this set are for identification purposes only. Inclusion of the names of the products or companies does not indicate a claim of ownership by IGI Global of the trademark or registered trademark.

Library of Congress Cataloging-in-Publication Data

Handbook of research on computer-enhanced language acquisition and learning / Felicia Zhang and Beth Barber, editors.

p. cm.

Summary: "This book provides comprehensive coverage of successful translation of language learning designs utilizing ICT in practical learning contexts. It offers researchers, scholars, students, and professionals worldwide, access to the latest knowledge related to research on computer-enhanced language acquisition and learning"--Provided by publisher

Includes bibliographical references and index.

ISBN-13: 978-1-59904-895-6 (hardcover)

ISBN-13: 978-1-59904-896-3 (ebook)

1. Language and languages--Computer-assisted instruction. I. Zhang, Felicia. II. Barber, Beth.

\author{
P53.28.H36 2008
}

$418^{\prime} .00285--\mathrm{dc} 22$

\title{
2007036856
}

British Cataloguing in Publication Data

A Cataloguing in Publication record for this book is available from the British Library.

All work contributed to this book set is original material. The views expressed in this book are those of the authors, but not necessarily of the publisher.

If a library purchased a print copy of this publication, please go to http://www.igi-global.com/reference/assets/IGR-eAccess-agreement. pdffor information on activating the library's complimentary electronic access to this publication. 


\title{
Chapter VII \\ Computer-Enhanced Grammar Teaching
}

\author{
David Barr \\ University of Ulster, Northern Ireland
}

\begin{abstract}
This chapter reports on the results of a study undertaken to gauge what difference computer technology makes to grammar learning. Unlike other studies that compare the student performance learning grammar with the aid of technology to performance and without the technology, this work focuses on the impact technology has on student attitudes towards learning grammar through the computer. The chapter outlines how traditional grammar classes have been adapted for delivery in a multimedia situation and assesses the impact, both in terms of students' perceptions about learning of grammar and in their actual performance that the computer has had on the process. The chapter also draws on the lessons learned in this project to help to maximise the potential of using technology in this type of teaching and learning context in the future.
\end{abstract}

\section{INTRODUCTION}

Studies have shown that the transition between school and university can be difficult (Martinez, 2001). There are many reasons for these difficulties, including adjustment to a new teaching environment. Students often require a period of readjustment and training to encourage them to become more active, constructivist learners and to extend the learning experience beyond the classroom (Fry \& Ketteridge, 1999, p. 37). Within the area of language learning, implicit grammar teaching can be seen as one way to promote active learning and develop learner responsibility (Davies \& Williamson, 1998). Adamson (1998) points out, however, that this is not always the best way for students to learn grammar and Schulz's (2001) examination of the importance of corrective feedback from teachers points convincingly towards a need to ensure that students are not 
left entirely to their own devices in the study of grammar. Furthermore, Krashen (1999) points out that post secondary language students are not only used to formalised grammar teaching, but expectit. This suggests that despite the importance of students taking more responsibility for their learning, the study of grammar is one area where they need explicit guidance, especially in the early stages of their post secondary education.

The use of computer programs to guide and support students in their learning is not a new concept, in particular in the area of language study, which has been the subject of much research over the last two decades (See Levy, 1997, for example). In particular, the potential for using technology for teaching and providing explicit guidance in more mechanical areas of language learning, such as vocabulary acquisition and grammar learning have been well documented (Powell, 1998; Sciarone \& Meijer, 1993). Studies also have been conducted comparing the use of a computer-based approach to a traditional teacherdirected approach to determine whether one is better than the other. One of these (Nutta, 1998) provides some quantitative conclusions showing that the computer-based approach is more effective for grammar teaching than the teacher-directed approach. Many of these studies tend to point towards improvements in student performance in grammar related tasks. Nevertheless, success in teaching grammar needs to be examined in context. Despite the explosion in packages that teach grammar (and do so very well) over the past 20 years or so, Engel and Myles (1996) point towards the decline in the standards of grammar among students entering higher education: this means that more and more students are coming into university with a less developed appreciation of foreign language grammar and, as a result, considerable time needs to be spent at the early stages of their university career revisiting basic areas of grammar, which can sometimes have a demotivating effect on students. For some, the revision of basic grammar is seen as a step backwards (even though it probably is not); for others, the admission that they struggle with basic grammar is a source of personal embarrassment. In both cases, this can affect their willingness to contribute to or even attend grammar classes. This suggests that the issue to be addressed in the area of learning grammar is not only developing packages that teach grammar well and that produce quantifiable improvements in grammar acquisition but also that important changes are required in student attitudes and perceptions to motivate them to learn grammar.

In keeping with the research aims of the book, of which this chapter forms part, (i.e., to provide comprehensive coverage of successful translation of language learning designs utilizing ICT in practical learning contexts), this study will discuss the findings of a project that saw the teaching of French grammar move from a traditional teaching room to being taught in multimedia language computer rooms, thereby changing the entire dynamic of the teaching and learning experience. The chapter will examine whether technology has helped to change the attitude of students towards learning grammar through an initiative undertaken among first year undergraduates of French at the University of Ulster, many of whom had very different attitudes towards learning grammar. The work undertaken seeks to address two main research questions:

a. Does the use of technology make any qualitative difference to student attitude towards grammar work?

b. How do perceptions and qualitative evidence compare to quantifiable student performance?

The chapter will outline the stages involved in the project, before assessing whether engagement with a computer-based model for grammar learning had any impact on student learning. It will do this through quantitative study of the student cohort and also through a micro-analysis of 
the performance of six students. It also will use qualitative analysis to gauge student reaction to the use of computers for grammar learning. The chapter will then examine the effects of using a computer-based model for teaching and learning grammar before drawing on a number of lessons learned through the project.

\section{PROJECT STAGES}

If students are to take maximum benefit from grammar classes, it is important to address student perceptions of grammar learning, and to provide students with an opportunity to appreciate their weaknesses in grammar in an unobtrusive and more comfortable manner. The need to address student perceptions of grammar learning at the University of Ulster were borne out in the results of a questionnaire, administered at the beginning of semester 1 of the 2005/06 academic year to first year undergraduate students of French, which asked students about their perceptions and expectations of learning grammar. Thirty-five percent of respondents (where $\mathrm{N}=20$ ), felt that learning grammar was enjoyable (see Figure 1). The remainder said that learning grammar rated somewhere between of average interest to rather uninteresting. These figures suggest that students are not enthused about grammar classes, yet, as outlined above, grammar study remains an essential component of language learning that many students fail to grasp.

In this context, languages staff undertook an initiative aimed at consolidating and developing the grammar skills by attempting to change student perception about grammar classes. It also was hoped to encourage students to engage in a more active way with their grammar learning, to help address the Engel and Myles' concern about declining standards in grammar learning. The initiative was divided into three stages:

1. The completion of computerised diagnostics tests to identify strengths and weaknesses in the area of grammar.

2. To change the environment in which grammar classes take place by moving teaching from seminar/lecture rooms to multimedia learning laboratories.

Figure 1. Students attitude towards grammar administered at the beginning of the semester

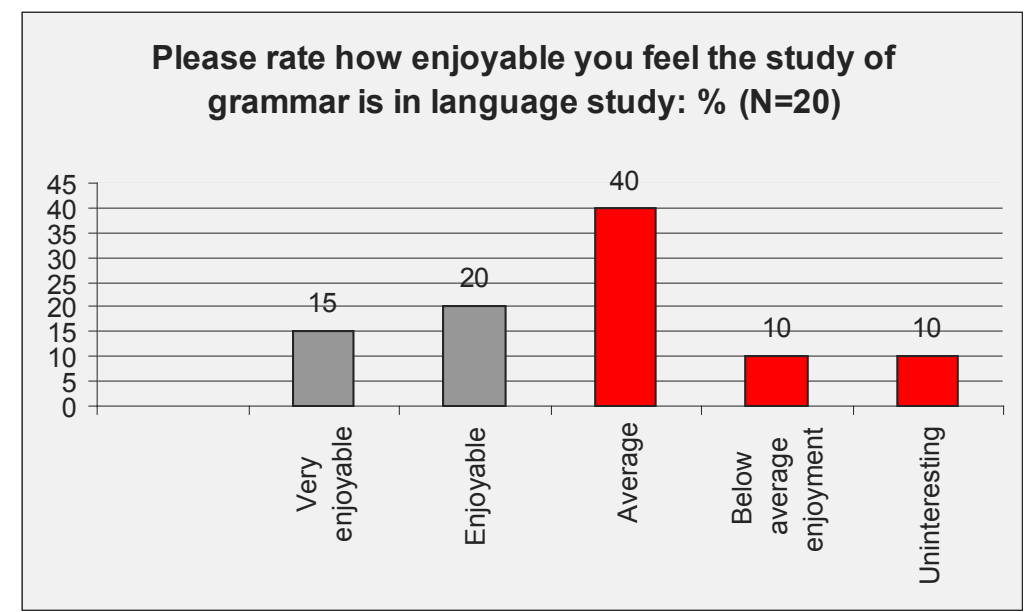


3. Encouraging students to use CALL exercises online outside class in an effort to strengthen key grammar concepts.

\section{Phase 1}

All students within a first year French grammar class completed a computerised diagnostic multiple-choice test at the start of semester. The purpose of the test was to assess the level of ability in main grammatical areas of French. The tests were completed using the Virtual Learning Environment, WebCT. The tests were completed electronically to facilitate greater re-usability as results were automatically collated on the system and the data displayed in a format that could be easily interpreted by tutors. The format provided the question, the possible answers and the percentage of students who chose each answer, with the correct answer highlighted. This provided the tutors with immediate feedback on student performance and, at a glance, they could see which questions were most problematic for the cohort of students. This provided a valuable insight for tutors as it allowed the tutors to focus in class on areas on grammar that the test had shown were particularly difficult for the students. The same test was taken again at the end of the semester (i.e., 11 weeks later) to gauge whether students had made progress in any of the areas of difficulty that had been highlighted in the initial test.

\section{Phase 2}

Grammar teaching has traditionally taken place in seminar or lecture rooms. In an effort to encourage greater student participation and involvement with this aspect of language study, it was decided to deliver grammar classes in a multimedia learning room to allow students to have greater ownership of their learning: ownership is one of the traits of active learning, as discussed by Reagan (Reagan, 1999). Furthermore, technology allows learners the freedom to work at their own pace and level (Hoven, 1999). In the multimedia lab, classes were split into two parts: the first stage would take the form of a grammar lecture where grammatical theory was discussed, often using PowerPoint

Figure 2.

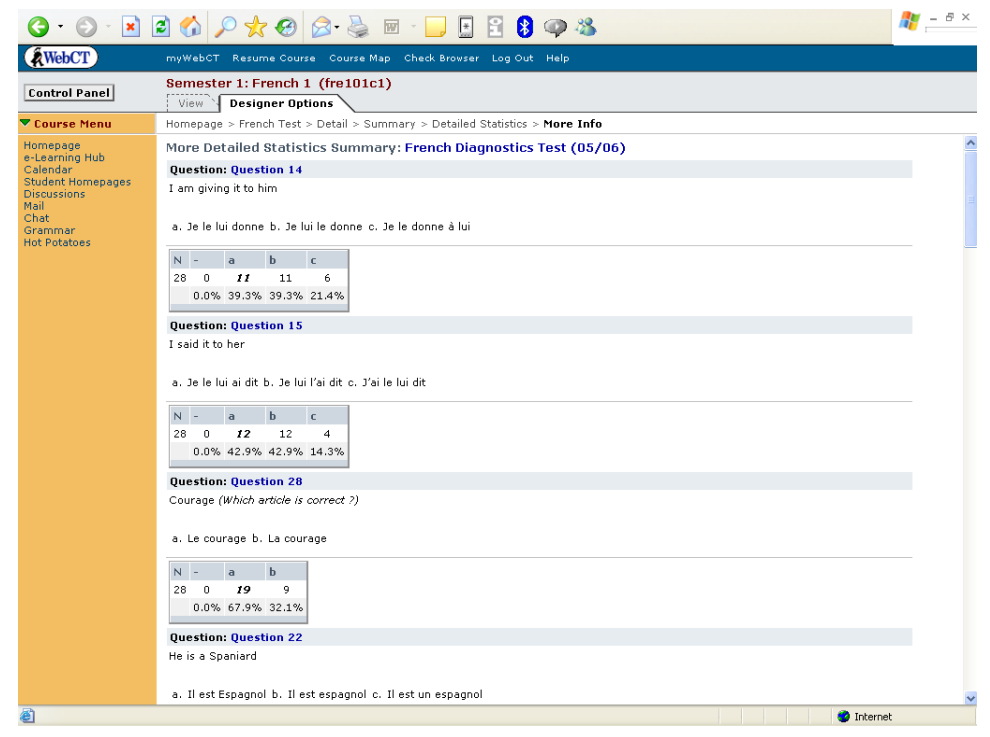


to deliver main ideas and concepts: these notes were subsequently posted within a course area on $W e b C T$, so that students could access information outside class. The theory was then supported by grammar exercises on the topics covered, many of which had been created online, using the Hot Potatoes authoring tool. These exercises were uploaded to a dedicated area on the Web, known as HotPotatoes.net.

\section{Phase 3}

In addition to completing some online exercises in class to assess their understanding of grammatical aspects under discussion, students were encouraged to continue working through these exercises in their own time and revisit exercises that they found most difficult. Students also completed a series of activities in Clef, a networked CALL program, available to students in the multimedia lab. Often, students would be directed to this material as an adjunct to the exercises on HotPotatoes.net and, in particular, students who had obtained low scores in their initial diagnostic test, were encouraged to complete remedial exercises on Clef.

\section{METHODOLOGY}

In measuring the effectiveness of this computerbased model, we need to be mindful of Thornbury, Elder, Crowe, Bennett, and Belton (1996) who believe the value of the technology is not necessarily measured on its technological excellence or astounding quality but rather on how well the technology is integrated into the teaching and learning experience. In other words, the role given to the technology in supporting and facilitating teaching and learning are important in assessing the overall success of a project like the one under discussion here. A broadly similar argument is offered by Felix (2005), In order to assess the level of integration, a number of data collection methods were used:

a. Questionnaires. Students were given questionnaires at the beginning and end of the semester. The first questionnaire $(\mathrm{N}=20)$ asked students to comment on their experiences of learning grammar to that point and the second questionnaires $(\mathrm{N}=21)$ asked students to provide qualitative feedback on the grammar classes: what they liked, disliked and their perception of the use of the technology.

b. The performance of each student in both diagnostics tests (28 in total) was analysed. More importantly, the tests were used to identify areas of improvement or lack of progress in key grammatical areas studied during the semester.

c. A micro-analysis of six students was conducted, mapping student use of HotPotatoes.net against student performance in the diagnostics test to examine the correlation between using the above computer technology and achievements in grammar learning.

\section{STUDENT PROGRESS QUANTIFIED}

The performance of the all students $(\mathrm{N}=28)$ has been analysed in Figure 3. The results show difference in performance on each question between the first and second tests across the entire cohort of students. This graph demonstrates that the student performance on some questions is better than on others and, in some cases, the performance is worse on the second test (questions four, seven, and eight). Clearly, other factors affect the performance of students; these include the level of study of grammar topics that students undertook independently of class, including revision from grammar books and the use of self-study packages 
Figure 3. Student cohort performance on each question in first and second tests

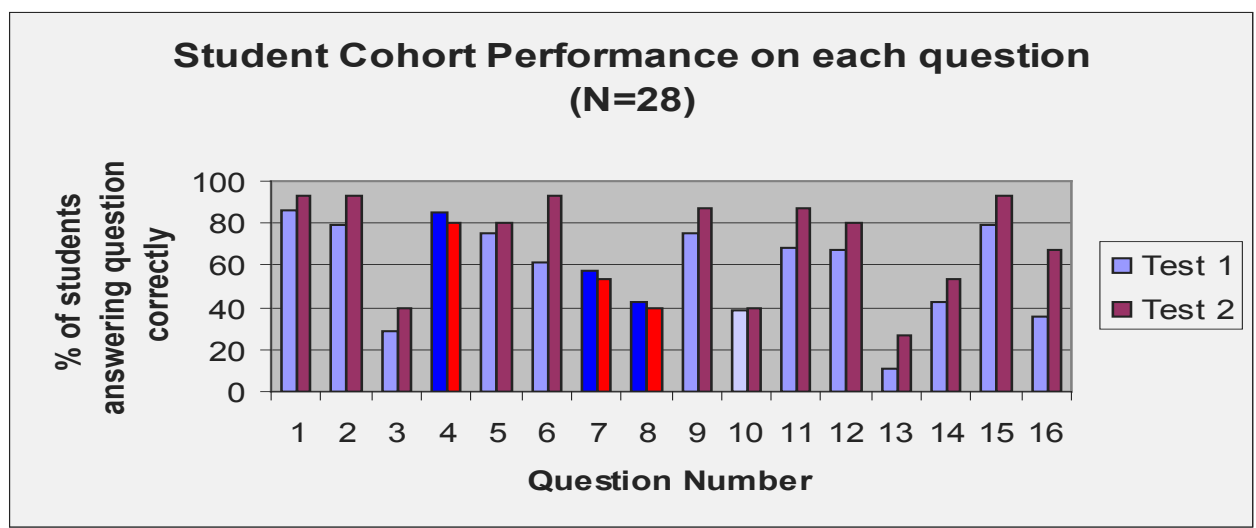

such as Clef. Furthermore, it might be expected that students would improve in the second test as the grammar areas that had been highlighted as deficient in the first grammar test were covered by the tutor in grammar classes throughout the semester.

\section{Micro-Analysis}

The results in Figure 3 show the enhanced performance in the second diagnostics test was not always evident across the entire cohort of students. The inconclusiveness of these results also is furthered evidenced by a micro-analysis of the performance of six students. These students were chosen based on their performance over both diagnostics tests and represent the top, middle and lower achievers in the class, reflecting the larger sample size of 28 .

\section{Student One}

This student scored 14 out of 20 in her initial diagnostics test on WebCT. This was the second highest score of the cohort. The second test saw a slight improvement (16 out of 20). It seems obvi- ous from these scores that this student had a good understanding of key grammatical concepts. A more detailed study of this student's performance showed that although she improved on one area of grammar in the second test, this area was not covered by the range of online material provided to the student. At the same time, however, the student in question undertook a large number of activities online (36). She concentrated on one area of grammar (the use of position of Direct and Indirect Object Pronouns) and repeated most of the exercises in this area at least twice. Interestingly, despite the practice, the student answered one of the two questions in this area incorrectly in the second diagnostics test. Her performance in the diagnostics test in this grammatical area and the number of attempts she made at the online exercises in that area show that this is clearly a difficult area for the student.

\section{Student Two}

Performance of this student in the diagnostics test was similar to that of Student One. He improved by three marks $(13 / 20$ in test 1 and $16 / 20$ in test 2). It may be unlikely that this can be attributed 
to practice in the online exercises, created using Hot Potatoes, as this student completed a small number of exercises online (a total of 12) and made no attempt to revisit any exercise to consolidate his understanding of the grammatical issues.

\section{Student Three}

This student scored 10 out of 20 in the first diagnostics test and there was a marginal improvement (11 out of 20) in the second test. This student carried out 20 exercises online in HotPotatoes. net, five of which were in one area of grammar (the Perfect tense). Interestingly, this was one of the areas where the student had improved between the first and second diagnostics test. Given the small improvement in the student score, it would be unwise to speculate that this improvement was due to the use of online exercises.

\section{Student Four}

This student made no improvement in terms of her result in the diagnostics test. In both, she scored nine out of 20. Somewhat paradoxically, this student had completed 26 grammar exercises online. Although there was no quantitative improvement or worsening of her result, three grammar areas that had been answered correctly in the first test was incorrectly answered in the second test. The student had, however, studied all these areas online. However, a further study of the student's results revealed that she had made no attempt to self-diagnose. In other words, there is no evidence that the student tried repeating exercises to improve on previous results. Had the student used the online material for the purpose of remedial practice rather than for one-offexercises, the results may have been different.

\section{Student Five}

This student scored six out of 20 in the first diagnostics test and there was a substantial im- provement in the second test (13 out of 20). This student carried out a total of 12 exercises online. This was the second lowest number of exercises completed on the online system, yet the improvement between the first and second diagnostics test was the most significant of the group. Nonetheless, like Student Four, this candidate had not made any attempt to revisit any of the exercise already completed for further practice.

\section{Student Six}

This student scored six out of 20 in her first diagnostics test and 12 out of 20 in her second. She completed 23 online grammar exercises. Although her score showed a noticeable improvement, it became clear, upon analysis, that the student had failed to make progress in three areas of grammar that had been practised quite extensively using the exercises on HotPotatoes.net.

The results from the micro-analysis of six students demonstrate further that the link between the use of computer-based grammar support and enhanced student performance in the online tests is tenuous. They highlight an issue raised by Chapelle and Hegelheimer (2000) that "linguistic input, such as that received through CALL materials, needs to become intake in order to be acquired by the learner" (p. 42). This means if CALL materials, such as those created online using Hotpotatoes.net, are to be effective, the learner has to engage meaningfully with them. Success is therefore not measured on the number of exercises completed but rather the thoroughness spent over each activity. Given that few students in this project used the online materials for continual practice, re-testing themselves at stages in the semester to ensure knowledge retention; it is not surprising that our quantitative results are inconclusive: effective learning requires the learner to play his part too. 


\section{STUDENT ATTITUDES TO THE USE OF ICT IN LEARNING GRAMMAR}

The previous section has shown that the progress made by students in their learning of grammar was not quantifiably improved by the use of computer technology. Did that mean, however, that the attitudes of students to the use of the computer-based model were negative? At the end of the semester, students were asked to comment on the grammar classes and the general feeling was that the classes were enjoyable. Some of the comments made by the students are listed below:

"I think Hot Potatoes is a really good way of practicing grammar points."

"I liked it, was clear and helpful and easy to use and interesting."

"...like the way you have to keep working before you are given a clue or answer."

"I think that Hot Potatoes was an excellent way to learn main grammar points."

Furthermore, 70 percent of respondents (where $\mathrm{N}=13$ ), commented on the positive impact that technology brought to the class. Although this cohort is small, the overwhelmingly positive feedback about the use of technology is significant. It suggests that the technology impacts upon student attitudes. Furthermore, it implies that the technology can be used for intrinsically motivating students which, according to Newstead and Hoskins (1999), is central to the learning experience of higher education. This means encouraging students to enjoy their learning experience rather than solely to seek academic reward through high coursework marks.

What factors may explain the positive reaction of students? Gillespie and McKee (1999) established a number of factors that influence student attitudes. These can be divided into psychological, infrastructural and educational factors.

\section{PSYCHOLOGICAL FACTORS}

Increasingly, computer technology has become such an integral and everyday aspect of student lives, with many students coming to university already having used computers extensively in primary and secondary schools (Cuban, 2001). At the same time, however, in their analysis of student reaction to the use of ICT in language learning, Gillespie and McKee, (1999) found that students feel insecure when using computers for language learning and seek reassuring guidance from teachers. In other words, although students may be very computer literate, they do not necessarily know how to use computers for language learning, especially at the early stages of their study at university. In the project discussed in this chapter, the teacher's role in this project was central: ranging from explaining the grammar theory to monitoring student progress as they worked through the online exercises, either by walking around the classroom and answering questions or by viewing the scores that students obtained in their exercises. Students in this project seemed to find the role of the teacher essential. Their observations cited "human" aspects of class (explanations given by teachers, atmosphere in class...) as the important/influencing factors in class (cited by 77 percent of respondents). This view is supported by Tharp and Gallimore's model of Vygotsky's Zone of Proximal Development (1988). In their model, Tharp and Gallimore (1988) state that there are a number of stages to effective learning: stage one is called "assistance by more capable others" (an expert teacher, student peer or even a computer). The second stage requires "assistance by the self." In other words, in addition to support from the teacher, the student needs to engage with what he is learning. 
One way of achieving this is to retain student interest in what he is doing. Warschauer (1996), for example, believes that an amalgam of different computer-based approaches is necessary to achieve effectiveness. This means that instead of always using one piece of software or hardware, students' interest is best retained if various media can be used. In this project, students used online exercises on HotPotatoes.net, a local based dedicated software, such as Clef and accessed grammar notes on WebCT. Each had their own interface and students therefore needed to learn how each one operated, thereby giving the students fresh stimulus throughout the course of activities. There is, of course, a danger of information overload and if the range of activities becomes too complicated and varied, there is greater potential for students to feel insecure and lost, with the result that the learners "switch off" and, far from feeling stimulated, do not engage with the resources and material: a view echoed by Gillespie and McKee (1999).

These observations suggest that, in the students' opinion, the technology did not dominate the classroom experience. The realisation that the computer technology is not all-encompassing (but rather has a supporting role) and is a means to an end rather than an end in itself is key if successful integration of CALL into the teaching and learning process is to be achieved (See McCarthy, 1999).

In addition, this project sought to ensure that the use of computer technology in their learning did not represent too drastic a culture shock for the students. Ninety-five percent of respondents in the first questionnaire noted that they have traditionally learned grammar by completing written exercises in class. In this cohort, students used the technology for the same purpose: they completed exercises to drill them on key grammar concepts. Barr discovered that students are not as radical as we might think when it comes to embracing technology (2004) and this would suggest that students do not necessarily enjoy using technology for tasks with which they are not familiar. Since they are familiar with the concept of learning grammar by completing exercises, using the Web for this task is not that radical a change for them and therefore does not take them too far outside their comfort zone.

The reaction of students reveals another important aspect of using technology to enhance the student learning experience: the computer refocuses attention in class. Stepp-Greaney (2002), quoting Hartman, Neuwirth, Kiesler, Sproull, Cochran, Palmquist, and Zabrow, states that "the use of technology redistributes ... classmate attentions"(p. 165). This allows the students to hide their performance (and embarrassment over poor performance) from the rest of the class, which, in turn, may encourage students to loose their inhibitions about answering questions through fear of giving the wrong answer - an issue that can often affect the dynamic of classes. The "virtual" environment, therefore, encourages enhanced class participation by students.

\section{INFRASTRUCTURAL FACTORS}

Another factor that influences student attitudes to the use of ICT in language learning, according to Gillespie and McKee, relates to the infrastructure within which students work. By focusing the activities in class around the use of computer technology, there was a real danger of increasing the pressure on the hardware and software, leading to such problems like slow network speeds and difficulty accessing the Hotpotatoes.net server could have caused frustration among students, with a real danger that this could become a major source of discouragement for students, even causing resistance (see Esch \& Zähner, 2000; Kung \& Chuo, 2002). In addition, the classes in this study took place in multimedia language learning labs. Students were encouraged to work on the online 
materials and use the locally-based dedicated grammar software available in the labs in their own time outside class. The teaching labs were open from 9:00am to 5:00pm every day (Monday to Friday) and, whereas students could use the labs in their own time during the day, the labs were heavily booked for teaching purposes. This meant that students had restricted access to the labs. Nevertheless, students also had access to a self-study resource area called the Multimedia Resource Unit. This facility operated the same opening hours as the multimedia labs but was not used for teaching purposes, meaning that it was much more accessible for students. It also contained a number of PCs that provided the same range of dedicated language learning software as the teaching labs. Furthermore, the exercises uploaded to Hotpotatoes.net and the provision of notes on $W e b C T$, meant that some resources were available on the Web and could be accessed from any PC, so if the multimedia labs were occupied and the PCs in the Multimedia Resource Unit were all being used, students could use any other PC lab on campus or could even access the exercises from their own computer, either in halls of residence or from home.

According to the results of the second questionnaire, only two students commented on hardware or software difficulties with either the online exercises or, more generally, with the computer environment (access to computers/labs...). We might assume that technological difficulties did not have an impact on the attitudes of students towards the computer-based model. It is likely that if students could not access the grammar software outside class time, in the Multimedia Resource Unit or online, for example, student feedback would have been less positive. This highlights an important issue for colleagues seeking to integrate computer technology into their teaching. If students are expected to use hardware and software outside teaching time, they need adequate access to the resources.

\section{EDUCATIONAL FACTORS}

Incompatibility with the modern languages curriculum has been blamed for students reacting negatively to the use of computer technology in their learning (Gillespie 1995). In other words, if students feel that the use of computer technology does not help them in their learning, they are likely to be unwilling to embrace its use. The quantitative evidence presented above shows that there is little sign that the use of technology in this project produced "actual" benefits for the students, as their academic performance was not significantly enhanced by using the computerbased model. That said, however, the use of technology can have affective benefits. According to Stepp Greenay (2002), if students enjoy using the technology and feel there are benefits to using it, this influences student perceptions and attitudes towards learning and ultimately gives them a more positive outlook on their learning. Consequently, perceptions that students have about using the technology for learning grammar can be just as important as evidence of improvements in results. In their initial questionnaire, 85 percent of students rated the study of grammar as very important and the remaining 15 percent said they felt that the study of grammar was important. These figures seem to suggest that the students understood the importance of learning grammar and, given that the purpose of using the computer-based model in this project was to help students to learn grammar more effectively, we might infer that students could see that technology was being used as a means to help them learn what they all perceived as fundamental area of language learning.

This is further supported by feedback from the second questionnaire, which showed that students wanted to have more exercises on the online system. This suggests that they see clearly the advantages of completing exercises online. We might assume that one of main advantages of completing online exercises is the instant feedback 
they can provide - a view that is shared by Schulz (2001). In the first questionnaire, 95 percent of respondents remarked on the need for good feedback in grammar testing. The online exercises that students completed provided feedback, hints and tips for particular grammar points. As a result, it became clear to students that completing the exercises online provided them with feedback that may have otherwise been missing in other forms of grammar drilling. That does not mean that feedback was adequate for all students. In fact, in the small number of cases where students used the online system for continued practice of particular grammar points, this did not guarantee improvement in that area in the final diagnostics test, which suggests that more explicit feedback and perhaps tailored learning paths may have been useful.

We can see the value of student perceptions in Conole's taxonomy of effective learning. Her triangular representation of learning activity (Figure 4) establishes that effective learning is only possible if based around pedagogy, tasks and context. Without any of the three, the process is incomplete. By examining the computer-based model in this study, we see that the technology provides the backdrop for the elements - the setting of the computer lab represents the context, the use of online exercises constitute the second element - the tasks and a range of pedagogical approaches are used (teacher-centered theoretical explanations and student-centered activities). However, these three elements require something to bring them together to form a coherentstructure. That is where the learner plays his part. Without the willingness of the learner to engage with the tasks, work in the context provided and engage with the pedagogy, the triangle is incomplete and effective learning is not possible. Clearly, if students enjoy what they are doing and feel it is bringing benefit to them (such as instant feedback), they may be more willing to engage more actively in their learning activity.

\section{CONCLUSIONS}

The results of this paper show a number of important findings. In response to the research questions posed earlier, we can conclude the following:

Figure 4. Conole's Taxonomy of effective learning (Copyright 2007, Gráinne Conole. Used with permission.)

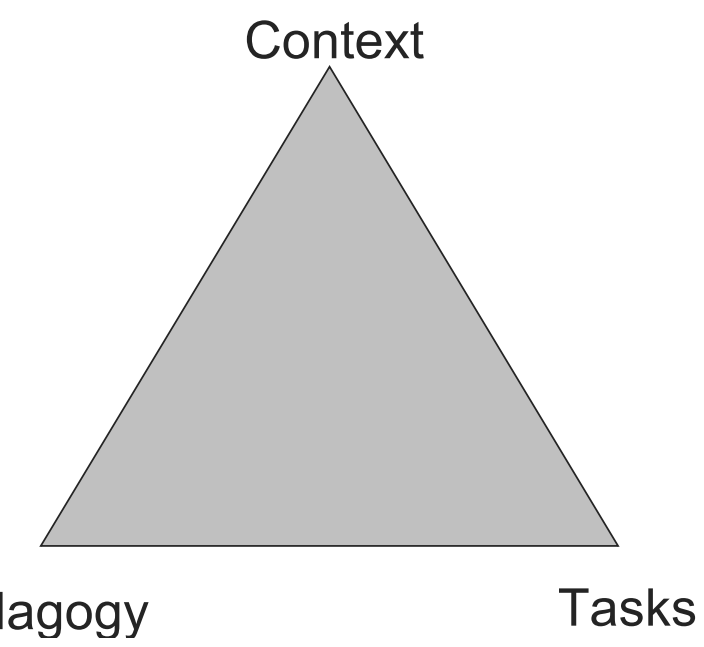


1. Doestheuse of technologymake anyqualitative difference to student attitudes towards grammar work? The students generally reacted positively to the use of a computerbased model in grammar teaching and that seemed to encourage the students to engage with their grammar learning and enjoy grammar classes, so we can conclude that qualitatively the technology made a difference as it changed students' attitudes towards learning grammar. The study also showed that there were a range of psychological, infrastructural and educational factors that influenced student reaction to the use of ICT in their learning of grammar. Whereas, the scale of this study is quite small, it further supports the studies of Barr (2004) and Gillespie and McKee (1999) on student attitudes.

2. How do perceptions and qualitative evidence compare to quantifiable student performance? There is little quantifiable evidence to prove that the use of technology improved students' ability in grammar, at least in terms of their performance in grammar tests. Given the short time scale for the project (one semester of 12 weeks), it is most likely that a longer study would be needed to answer the question with any conviction.

These findings show that the technology has a valuable role to play in the teaching and learning of grammar, especially in terms of influencing the attitudes of students. Although we cannot say whether the model outlined here is a success in terms of academic performance, the use of the model has had a direct influence on student perceptions about learning grammar and if students enjoy using computer technology and the conditions are right for doing so, the learning experience can be made more enjoyable. This is not without worth in an academic world that is increasingly focusing on student retention.

\section{REFERENCES}

Adamson, R. (1998). Modern Language teaching and grammar: An explicit relationship? S. Hotho (Ed.), Forum for Modern Languages Studies Language Teaching and Learning: current trends in Higher Education, 34(2), 170-183.

Barr, D. (2004). Students and ICT: An analysis of student reaction to the use of computer technology in language learning. IALLT Journal, 36(2), 19-39.

Chapelle, C., \& Hegelheimer, V. (2000). Methodological issues in research on learner-computer interactions in CALL. Language Learning and Technology, 4(1), 41-59.

Conole, G. (2006, January). Mediating artefacts to guide choice in creating and undertaking learning activities. Paper presented at E-Learning Conference, University of Ulster, Coleraine.

Cuban, L. (2001). Oversold and underused: Computers in the classroom. Cambridge, MA: Harvard University Press.

Davies, T., \& Williamson, R. (1998). The ghost in the machine: Are "teacherless" CALL programs really possible? Canadian Modern Languages Review, 55(1), 8-18.

Engel, D., \& Myles, F. (1996). Grammar teaching: The major concerns. In D. Engel \& F. Myles (Eds.) Teaching grammar: Perspective in higher education (pp. 9-19). London: Association for French Language Studies and Centre for Information on Language Teaching and Research.

Esch, E., \& Zähner, C. (2000). The contribution of Information and Communication Technology (ICT): To language learning environments or the mystery of the secret agent. ReCALL, 12(1), 5-18.

Felix, U. (2005). What do meta-analyses tell us about CALL effectiveness? ReCALL, 17(2), 269288. 
Fry, H., Ketteridge, S., \& Marshal, S. (1999). Understanding student learning. In H. Fry, S. Ketteridge, \& S. Marshall (Eds.), A handbookfor teaching and learning in higher education (pp. 21-40). London: Kogan Page.

Gillespie, J. H. (1995). The integration of CALL tools into the Modern Languages Curriculum: A case study. In B. Rüschoff\& D. Wolff(Eds.), CALL \& TELL in Theory and Practice: the Proceedings of EUROCALL 1994 (pp.143-156). Szombathely: Dániel Berzsenyi College.

Gillespie, J. H. \& McKee, R. J. (1999). Resistance to CALL: Degrees of student reluctance to use CALL and ICT. ReCALL, 11(1), 38 - 46.

Hoven, D. (1999). A model for listening and viewing comprehension in multimedia environments. Language Learning and Technology, 3(1), 88-103.

Kung, S-C., \& Chuo, T-W. (2002). Students' perceptions of English learning through ESL/EFL Web sites. TESL-EJ, 6(1). Retrieved June 4, 2007, from http://www-writing.berkeley.edu/TESLEJ/ej21/a2.html

Krashen, S. (1999). Seeking a role for grammar: A review of some recent studies. Foreign Language Annals, 32(2), 245-257.

Levy, M .(1997). Computer-based language learning: Context and conceptualization. Oxford: Clarendon.

Martinez, P. (2001). Improving student retention and achievement: What we know and need to find out. London: Learning Skills Development Agency.

McCarthy, B. (1999). Integration: The sine qua non of CALL. CALL-EJ online, 1(2). Retrieved January 20,2006 , from http://www.tell.is.ritsumei. ac.jp/callejonline/journal/1-2/mccarthy.html

Newstead, S. E., \& Hoskins, S. (1999). Encouraging student motivation. In H. Fry, S. Ketteridge,
\& S. Marshall (Eds.), A handbook for teaching and learning in higher education (pp. 70-82). London: Kogan Page.

Nutta, J. (1998). Is computer-based grammar instruction as effective as teacher-directed grammar instruction for teaching $\mathrm{L} 2$ structures? CALICO, 16(1), 49-62.

Powell, B. (1998). The use of computer-assisted language-learning. Forum for Modern Language Studies, 34(2), 184-194.

Reagan, T. (1999). Constructivist epistemology and second/foreign language Pedagogy. Foreign Language Annals, 32(4), 413-425.

Schulz, R. (2001). Cultural differences in student and teacher perceptions concerning the role of grammar instruction and corrective feedback: USA-Colombia. The Modern Language Journal, 85(2), 244-256.

Sciarone, A. G., \& Meijer, P. J. (1993). How free should students be? A case from CALL: Computer-assisted language-learning. Computers and Education, 21(1/2), 95-101.

Stepp-Greany, J. (2002). Student perceptions on language learning in a technological environment: Implications for the new millennium. Language Learning and Technology, 6(1), 165-180.

Tharp, R. G., \& Gallimore, R. (1988). Rousing minds to life. New York, NY: Cambridge University Press.

Thornbury, H.., Elder, M., Crowe, D., Bennett, P., \& Belton, V. (1996). Suggestions for successful integration. Active Learning, 4, 18-23.

Warschauer M. (1996). Computer Assisted Language Learning: an Introduction. In S. Fotos (Ed.), Multimedia Language Teaching (pp. 3-20). Tokyo: Logos International. 


\section{KEY TERMS}

CALL Integration: The factors that influence how ICT is integrated into language teaching.

Computer-Based Learning Approaches: Examples of how to embed computer technology in learning and teaching.

Grammar Learning: How computer technology can enhance/affect the process of learning grammar.
Online Learning: The use of Web-based technologies for language learning.

Pedagogical Development: Lessons that can be learned in the pedagogical planning of language classes using ICT.

Student Attitudes: The attitudes of students towards use ICT in language learning and what factors may change these. 